\title{
Effects of Perches on Behavior and Performance of Caged Hens
}

\author{
Toshio Tanaka, Toshikazu Ozaki, Tamiko Watanabe, \\ Hajime TANidA and Tadashi Yoshimoto
}

School of Veterinary Medicine, Azabu University, Sagamihara-shi 229

\begin{abstract}
The objective of the present study was to compare the behavior and production performance of laying hens housed in cages with and without perches. Thirty-six commercial laying hens were divided into 3 groups of 12 each. They were subjected to the following types of cage with 2 birds per cage $\left(474 \mathrm{~cm}^{2} / \mathrm{bird}\right)$, according to the Latin square methods: $\mathrm{C}$, conventional cages without perches; $\mathrm{PN}$, conventional cages with perches from $20: 00$ to $08: 00 \mathrm{~h}$; PD, conventional cages with perches in whole days. Each experimental period consisted of 2 weeks. The proportion of birds resting (not eating, drinking, preening, aggression and walking) in C, PN and PD was $74.3 \%, 76.6 \%$ and $81.3 \%$, respectively. More than $90 \%$ of birds resting in PN and PD used the perches during the dark period. In PD, more than $70 \%$ of birds resting used the perches in the daytime. The production performance was not affected by the existence of perches. However, as the significant positive transitions from pacing to eating and drinking, and from aggression to eating and vice versa were observed in only PD cages, the perches in the center of cages might prevent hens moving.
\end{abstract}

(Jpn. Poult. Sci., $30: 183-189,1993)$

Key words : perch, behavior, productivity, welfare, laying hens

\section{Introduction}

In recent years, the battery cage system has been discussed to improve the rearing condition of hens from a viewpoint of animal welfare. One possible improvement is a cage equipped with a perch. RuszLer and QuisenBERRY (1970) found that perches resulted in highly significant improvements in livability and eggs per hen housed. LUESCHER et al. (1982) reported that no significant differences between cages with and without perches were found in number of eggs laid, egg quality traits, and the scores for feathering and excitability. They observed that most of resting time at night was spent sitting on the perch in hens housed in 2 birds per cage. TAuson (1984), however, showed that the hens in cages with a perch had significantly lower egg weight and higher frequency of cracked eggs, and he observed no significant difference between cages with and without perches in frequency of feeding or drinking behaviors. These results of previous studies varied in the effects of perches on performance of caged hens. In addition, behavioral study in such conditions has not been conducted enough yet.

The objective of the present experiment was to study the behavior and production performance of laying hens housed in cages with and without perches.

Received Oct. 16, 1992 


\section{Materials and Methods}

Thirty-six commercial egg laying type hens (Dekalb, 13 months old, $1.6-2.0 \mathrm{~kg}$ B.W.) were used in this study. The hens were divided into 3 groups of 12 each. They were subjected to the following types of cage with 2 birds per cage ( $240 \mathrm{~mm}$ wide, $395 \mathrm{~mm}$ deep, $434 \mathrm{~mm}$ high in the front and $390 \mathrm{~mm}$ high in the back; $474 \mathrm{~cm}^{2} /$ bird) in the environment controlled chamber, according to the Latin square methods: C, conventional cages without perches; PN, conventional cages with perches from $20: 00$ to $08: 00 \mathrm{~h}$; PD, conventional cages with perches in whole days. The wooden perch with a square section of $30 \times 40 \mathrm{~mm}$ was installed $80 \mathrm{~mm}$ above the cage floor and $180 \mathrm{~mm}$ from the front. Each experimental period consisted of 4 pre-experimental days and 10 experimental days. At $08: 00 \mathrm{~h}$, all groups were provided with $350 \mathrm{~g}$ of commercial semi-mash formula feed (CP, 16\%; ME, 2,900 kcal/kg) per cage. The feeder space was $160 \mathrm{~mm}$ per cage, and the birds had ad libitum access to feed and water. The room temperature was maintained at $22 \pm 1^{\circ} \mathrm{C}$ without humidity control $(50-70 \%$ of $\mathrm{RH})$. The illumination cycle was $14 \mathrm{~h}$ of light $(06: 00-20: 00 \mathrm{~h})$ and $10 \mathrm{~h}$ of darkness.

Using an infrared camera (National WV-CD 810) and a time-lapse video recorder (National NV-8450), the behavior patterns of each hen were observed for 3 whole days per experimental period, one group per day. The following activities were recorded in each 5-min interval : eating and drinking, preening, aggression, walking (stepping), resting and other. The behavioral data were analyzed by the analysis of variance (YosHida, 1978).

All activities of 4 hens in each group of all cage types from $13: 00$ to $15: 00 \mathrm{~h}$ were also recorded by the continuous focal animal sampling method. The activities were divided into the following categories : eating, drinking, preening and the other comfort behaviors, feather pecking, object pecking, head flicking (bobbing), pacing, aggression, walking (stepping) and resting. A $10 \times 10$ transition matrix consisting of a preceding behavior in a row and a succeeding behavior in a column was constructed to identify patterns of behavior, and a $z$-value for each transitions in the matrix was computed to test whether the number of observed transitions differed significantly from the expected value in which the transition was assumed to occur by chance (MARTin and BATESON, 1986).

Daily feed intake and egg production were recorded every cage. Egg shell weight was measured on random sample of 5 eggs per day per group in every periods, the last 3 consecutive days each. The productive data were analyzed by the analysis of variance (YosHIDA, 1978).

\section{Results}

The proportion of birds performing each behavior in a whole day except $1 \mathrm{~h}$ from 08 : 00 to 09 : 00 for routine work (feeding, measuring of feed intake, egg collection, etc.) is shown in Fig. 1. The proportions of birds eating and drinking in C, PN and PD cages were $17.4 \%, 15.4 \%$ and $12.7 \%$, respectively. Proportions of preening, 


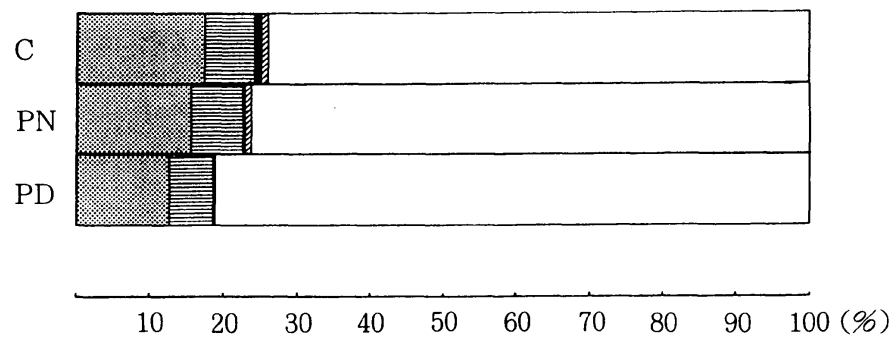

Fig. 1. Proportion of activities of hens during $23 \mathrm{~h}(09: 00-08: 00)$ period. $\mathrm{C}$, conventional cages without perches; PN, cages with perches from 20:00 to 08:00 h; PD, cages with perches in whole days. feeding and drinking; 冒, preening; $\square$, aggression; $\mathbb{Z}$, walking (stepping); $\square$, resting and other.

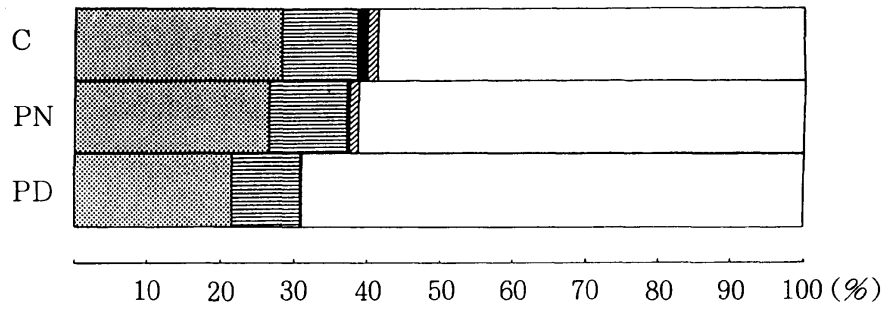

Fig. 2. Proportion of activities of hens during the light period $(06: 00-20: 00)$.

C, conventional cages without perches; PN, cages with perches from 20:00 to 08:00 h; PD, cages with perches in whole days. feeding and drinking; 冒, preening; $\square$, aggression; $\mathbb{Z}$, walking (stepping); $\square$, resting and other.

aggression, and walking in these three cages were as follows : $6.7 \%, 0.8 \%, 0.8 \%$ in $\mathrm{C}$; $7.0 \%, 0.3 \%, 0.7 \%$ in $\mathrm{PN}$; and $5.9 \%, 0.0 \%, 0.1 \%$ in PD. Therefore, the resting and other behavior occupied much more in $\mathrm{PD}$ than in $\mathrm{C}$ cages $(\mathrm{P}<0.05)$.

The behavior pattern during the light period is shown in Fig. 2, because most of dark period was spent on resting. The proportion of resting (not eating, drinking, preening, aggression and walking) in $\mathrm{PD}$ occupied $69.1 \%$ during the light period, and the value was significantly bigger than in $\mathrm{C}$ cages $(\mathrm{P}<0.05)$.

Table 1 shows the utilization of perches by hens. More than $90 \%$ of birds in PN and $\mathrm{PD}$ used the perches during the dark period. In PD, more than one half of birds perched in the daytime. Only the birds resting, 94\% of PN and 92\% of PD birds at night, and $71 \%$ of PD birds during the day spent on the perches.

The significant positive transitions between eating or drinking and other behaviors are shown as a flow diagram in Fig. 3. In PD, the transition from pacing to eating was significant, but not in $\mathrm{C}$ and $\mathrm{PN}$ cages. The significant transitions from aggression to eating and vice versa were observed in only $\mathrm{PD}$ cages.

Table 2 shows the production performance in each cage type. Daily feed intake, egg production, egg weight, and egg shell ratio were about $210-240 \mathrm{~g} /$ cage, $68-72 \%$, 
Table 1. Utilization of perches by hens

(mean $+\mathrm{SD}, \mathrm{n}=18$ cages)

\begin{tabular}{|c|c|c|c|c|}
\hline & \multicolumn{2}{|c|}{ Utilization of perches (sitting ${ }^{1)}$ ) } & \multicolumn{2}{|c|}{ Proportion of resting (on perches ${ }^{2)}$ ) } \\
\hline & Light & Dark & Light & Dark \\
\hline $\mathrm{C}$ & - & - & $\begin{array}{c}58.9 \pm 6.2 \\
(-)\end{array}$ & $\begin{array}{c}94.4+3.0 \\
(-)\end{array}$ \\
\hline $\mathrm{PN}$ & - & $\begin{array}{c}93.0+3.1 \\
(50.3+5.0)\end{array}$ & $\begin{array}{c}61.3+5.4 \\
(-)\end{array}$ & $\begin{array}{c}96.5 \pm 1.9 \\
(94.0+2.7)\end{array}$ \\
\hline PD & $\begin{array}{c}56.9+6.9 \\
(28.1 \pm 2.9)\end{array}$ & $\begin{array}{c}91.3+3.5 \\
(50.9 \pm 4.7)\end{array}$ & $\begin{array}{c}69.1+5.8 \\
(70.9+4.7)\end{array}$ & $\begin{array}{c}97.3+2.0 \\
(91.8 \pm 3.6)\end{array}$ \\
\hline
\end{tabular}

$\mathrm{C}$, conventional cages without perches; $\mathrm{PN}$, cages with perches from $20: 00$ to 08 : $00 \mathrm{~h} ; \mathrm{PD}$, cages with perches in whole days.

1) Proportion to the birds on perches.

2) Proportion to the birds resting.

Table 2. Production performance of hens

\begin{tabular}{lrrr} 
& \multicolumn{1}{c}{ (mean \pm SD, n = 18 cages) } \\
\hline Daily feed intake (g/cage) & \multicolumn{1}{c}{$\mathrm{C}$} & \multicolumn{1}{c}{ PN } & \multicolumn{1}{c}{ PD } \\
Egg production rate $(\%)$ & $240.0 \pm 44.4$ & $220.6 \pm 28.5$ & $208.9 \pm 42.9$ \\
Egg weight $(\mathrm{g})$ & $72.0 \pm 17.5$ & $72.5 \pm 12.5$ & $68.0 \pm 19.0$ \\
Egg shell ratio $(\%)$ & $65.0 \pm 2.8$ & $64.5 \pm 2.8$ & $64.8 \pm 2.6$ \\
Feed efficiency & $9.4 \pm 0.3$ & $9.3 \pm 0.1$ & $9.3 \pm 0.3$ \\
Body weight change $(\mathrm{g})$ & $39.0 \pm 4.5$ & $43.0 \pm 4.0$ & $42.0 \pm 4.7$ \\
\hline
\end{tabular}

$\mathrm{C}$, conventional cages without perches; $\mathrm{PN}$, cages with perches from $20: 00$ to $08: 00 \mathrm{~h}$; PD, cages with perches in whole days.

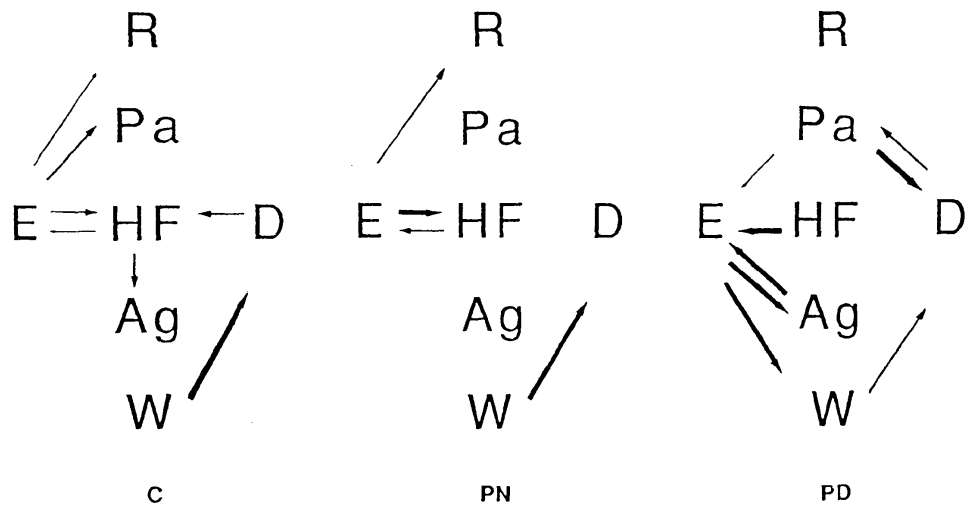

Fig. 3. The behavior sequence in laying hens.

$\mathrm{C}$, conventional cages without perches; PN, cages with perches from 20:00 to 08:00 h; PD, cages with perches in whole days.

$\mathrm{E}$, eating; $\mathrm{D}$, drinking ; $\mathrm{R}$, resting ; $\mathrm{Pa}$, pacing; $\mathrm{HF}$, head flicking ; $\mathrm{Ag}$, aggression; W, walking (stepping).

$\longleftarrow, \mathrm{P}<0.05 ;-, \mathrm{P}<0.01 ; \longleftarrow, \mathrm{P}<0.001$. 
$65 \mathrm{~g}$, and $9.3-9.4 \%$, respectively in all cage types. Feed efficiency of the birds in cages with perches was slightly improved because of the lower daily feed intake and almost the same egg production. Body weight change during the experimental period was not so much in all groups.

\section{Discussion}

It is known that hens show the preference for shape of perches. They prefer rectangular or circular perches rather than triangular ones (MUIRURI, et al., 1990). TAUSON (1984) reported that the productivity of hens in cages with circular perches was lower than that of controls in non-perched cages, and foot damage was less in birds with rectangular perches than with circular perches (DUNCAN et al., 1992). Therefore, the rectangular perches were selected in the present study.

The proportion of active birds decreased and resting birds increased with prolongation of available time of perches. WeBster and Hurnik (1990) also showed that resting occurred more in cages with perches. DUNCAN et al. (1992) reported that the position where the birds preened and rested was changed by the perch arrangement. Most of the birds resting used the perches, especially in the dark period, and LUESCHeR et al. (1982) also observed that up to $90 \%$ of birds' resting time at night was spent sitting on the perches. Therefore, cages with perches might provide hens with more comfortable environment.

On the other hand, the significant positive transitions from pacing to eating and drinking, and from aggression to eating and vice versa were observed in only PD cages. It is known that the intense frustration like a thwarting of feeding behavior led stereotyped pacing and escape movement (DUNCAN and WooD-Gush, 1972 ; TANAKA et al., 1992). This probably means that perches in the center of cages prevented hens moving.

LUESCHER et al. (1982) and WeBster and HuRnik (1990) reported that the production performance was not affected by the existence of perches. The results of this study agree with them, but the body weight of birds in perched cages decreased a little and the feed efficiency of them was slightly improved. As there was a large difference of data among cages, more birds should be used in the future study.

It was reported that the perches in the cages affected the feathering of birds and the proportion of cracked eggs (WeBster and Hurnik, 1990 ; Duncan et al., 1992). In the present study, however, the feathering was not recorded, because the feather condition of each hen had already varied at the start of the experiment. As there were some eggs which did not roll out from the cages in any cage types, the effect of perches on the proportion of cracked eggs was not clarified.

On the basis of these results, it was concluded that the cages with perches might provide hens with better environment than those without perches. Additional research will be necessary to clarify the most suitable installation of perches with the group size and density concerned. 


\section{References}

Duncan, E.T., M.C. Appleby and B.O. Hughes (1992) Effect of perches in laying cages on welfare and production of hens. British Poultry Science, $33: 25-35$.

DunCAN, I.J.H. and D.G.M. WooD-GuSH (1972) Thwarting of feeding behavior in the domestic fowl. Animal Behaviour, 20 : 444-451.

Luescher, U.A., J.F. Hurnik and J. Pos (1982) New cage design for laying hens. Poultry Science, $61: 606-607$.

Martin, P. and P. Bateson (1986) Measuring Behavior: An Introductory Guid. lst ed., pp. 63-66. Cambridge University Press, Cambridge.

Muiruri, H.K., P.C.Harrison and H.W. Gonyou (1990) Preferences of hens for shape and size of roosts. Applied Animal Behaviour Science, 27 : 141-147.

Ruszler, P.L. and J.H. QuisenserRy (1970) The effect of perches on various performance factors of caged layers. Poultry Science, 49 : 1433.

Tanaka, T., H. Hosoya, T. Watanabe, H. Tanida and T. Yoshimoto (1993) Effects of type of cage front on behavior and performance of laying hens. Japanese Poultry Science, $30: 24-30$.

TAUSON, R. (1984) Effects of a perch in conventional cages for laying hens. Acta Agriculturae Scandinavica, 34 : 193-209.

Yoshida, M. (1978) Design of Experiments for Animal Husbandry, 2nd ed., pp. 101-116. Yokendo, Tokyo. (in Japanese)

WeBster, A.B. and J.F. Hurnik (1990) Behavior, production, and well-being of the laying hen. 1. Effects of movable roosts, relationship of cage mates, and genetic stock. Poultry Science, 69 : 2118-2127. 


\title{
止り木の設置がケージ飼育産卵䊿の行動と 生産性に及ぼす影響
}

\author{
田中智夫・尾崎寿一・渡邊民子 \\ 谷田 創・吉本 正 \\ 林们大学獣医兴部，怛模原市 229
}

ケージに止りイを設置することによる産卵鶏の行動と 生産性への影響について検討した。36羽の白色レグホ ーン系産卵鶏を供試鶏とし，12 羽ずっ 3 群に分けた。 市販の 2 羽用産卵鷂ケージ（C）と, それに止り木を夜 閒だけ（20：00-08：00）設置した区（PN）および終日 設置した区（PD）を設け，ラテン方格法に従って 3 期 間（1期 2 週閒）夹験を行った。1日に上める休息行動 の割合は, C, PN, PD 区の順に有意に増加し, 明期中 だけを見ても PD 区が有意に多かった。休息中におけ る止り木の利用割合は, 夜䦌では PN, PD 区ともに 90 \%を越え，ほとんよ゙が止り木上で休息睡眠をとってい
た。PD区における明期中の休息時においても $70 \%$ 以 上が止り木を利用していた。また，止り木設置区におい て闘争行動が減少する傾向が見られた。生産性には区間 に差は認められなかった。しかし，PD区において，葛 藤時に見られるぺーシングから採食および飲水への有意 な行動連鎖が見られ，㹟い2 羽用ケージの山央を止り木 で分けられることによって逆に行動が制約されることも 亦唆された。

（家禽会誌, $30 ： 183-189,1993$ ) キーワード : 止り木, 行動, 生産性, 福祉, 産卵鶏 